\title{
The dairy industry in Sri Lanka: current status and future directions for a greater role in national development
}

\author{
B.M.A.O. Perera and M.C.N. Jayasuriya* \\ ${ }^{\prime}$ Faculty of Veterinary Medicine and Animal Science, University of Peradeniya, Peradeniya. \\ 2 National Science Foundation, 47/5, Maitland Place, Colombo 07.
}

Submitted: 28 August 2008

\begin{abstract}
The role of livestock in agriculture in Sri Lanka is complex and significantly different from that of industrialized nations. Although the livestock sub-sector has contributed only around $1.2 \%$ to the national Gross Domestic Product (GDP), it has been a crucial source of high quality protein, minerals and vitamins to the population, by way of milk, meat and eggs. For many rural smallholder farmers, livestock are a 'living bank' that serves as a financial reserve for periods of economic distress.
\end{abstract}

In a global context the current status of the dairy industry in Sri Lanka is far below expectations, local production of milk having been able to meet only $30 \%$ of the demand. Whilst there have been many political, technical and socio-economic factors contributing to the virtual stagnation of the dairy industry in the country, the very low farm gate price being one of the major contributors to this, it appears that the sector cannot continue to survive as a subsistence based activity, because it is only a secondary source of income to the farming community. It is apparent that if dairy farming is to be a profitable venture, there is a need for the small holder farmers to consider dairying as a commercial enterprise and at the same time link with the large scale dairy farms. This would require major policy changes, with a strong commitment and sustained implementation strategy by the government in partnership with the private sector.

Keywords: Dairy, development, livestock, milk

\section{INTRODUCTION}

The land area under agriculture in Sri Lanka is around 2 million hectares, which is $30 \%$ of the country's total area of $65,610 \mathrm{sq}$. $\mathrm{km}$. Almost $75 \%$ of the agricultural land is under smallholdings, and the number of such holdings is estimated at 1.8 million, with over $90 \%$ of them having less than 2 ha. Almost one third of these smallholdings have a mixture of crops and livestock. The area of farm holdings with livestock is around 0.56 million ha, of which $99 \%$ are categorised as smallholdings. The total number of farmers involved in livestock production is estimated at 700,000 , and between $30-60 \%$ of gross farm income is generated from livestock activities ${ }^{1}$.

The agricultural sector contributes around $13 \%$ to the national Gross Domestic Product (GDP). It provides employment to about $33 \%$ of the labour force, surpassing the contribution of any other major sector. The livestock sub-sector contributes around $6 \%$ to the agricultural GDP and around $1.2 \%$ to the national GDP ${ }^{2}$.

Livestock play diverse roles in Sri Lankan agriculture. Primarily, they provide a crucial source of high quality protein by producing milk, meat and eggs. In addition, cattle and buffalo are a primary source of renewable and low cost draught power for a variety of agricultural operations and transport. Other subsidiary products include hides, skins and manure. Livestock also serve as a 'living bank' for many small farmers, cushioning the risks associated with crop production and providing a financial reserve during periods of economic hardship.

The population of ruminants (cattle, buffalo, goats and sheep) in Sri Lanka over the past eight years is given in Table 1 and the annual average per capita availability of milk and milk products during the same period are given in Table 2. The numbers of cattle and buffalo during the 1980s were estimated to be around 1.6 million and 0.8 million, respectively. However, the last islandwide census of agriculture conducted in 2002 showed 
that the populations of the two species had declined to 1.1 and 0.36 million, respectively. Since then there has been a gradual increase in both populations ${ }^{3}$.

The annual average per capita availability of milk and milk products has also shown only a marginal increase over the past decade (Table 2). On the other hand, as evident from Table 3, the annual average per capita consumption of meat as well as milk has increased markedly since the early 1990s. The greatest increase in consumption has been in chicken meat and milk powder.

The monthly average expenditure on livestock products by households in different sectors during 2006 is given in Table 4. As expected, the urban sector spends more on livestock products than either the rural or estate sectors.

From the forgoing it is apparent that although consumer demand for livestock products has increased, neither the numbers of livestock nor their productivity (with the exception of the poultry sector, which is not covered here), has shown any significant increase. The dairy sub-sector in particular has been stagnant over the past two decades, while imported milk powder has filled the gap between demand and local production. An important reason for this is that the majority of holdings in this sector continue to operate as a subsistence-based activity, being only a source of secondary income to the majority of livestock owners.
This situation is rather paradoxical, considering that successive governments have viewed the development of the livestock sector as an instrument for social and economic advancement of the rural poor, through employment, sustainable income and improved nutrition. The development of this sector will not only help to achieve food security, import substitution or even self sufficiency in animal products but also prevent the migration of rural poor to urban areas in search of supposed economic benefits. In order to fulfill this role, however, it is clear that the dairy sub-sector in particular needs to become more efficient and businessoriented. The operations at production level as well as the post-production value-chain involving processing and marketing need to be horizontally integrated, so that the farmers receive an economically attractive price for their products. This would provide the incentive for medium- and large-scale entrepreneurs to enter the field and make further investments that are necessary to make the national livestock industry more efficient and modernized.

\section{Current status of the dairy industry}

National milk consumption, national production and imports

As shown in Table 5, the current milk consumption in Sri Lanka is around 700 million litres per annum, which amounts to a per capita consumption of 35 litres per annum. The current national milk production of 220

Table 1: The population of ruminants in Sri Lanka, 2000 - 2007

\begin{tabular}{lrrrrrrrr}
\hline Animal Type & \multicolumn{7}{c}{ Number (x 1,000 heads) } \\
\hline & 2000 & 2001 & 2002 & 2003 & 2004 & 2005 & 2006 & 2007 \\
Neat cattle & 1,147 & 1,153 & 1,112 & 1,138 & 1,160 & 1,185 & 1,214 & 1,222 \\
Buffalo & 304 & 290 & 282 & 280 & 301 & 307 & 314 & 318 \\
Sheep/Goats & 506 & 504 & 360 & 423 & 416 & 405 & 395 & 405 \\
\hline
\end{tabular}

Source: Dept. of Census and Statistics, Sri Lanka ${ }^{3}$.

Table 2: Annual average per capita availability of milk and milk products, 2000 - 2006

\begin{tabular}{lccccccr}
\hline Product & 2000 & 2001 & 2002 & 2003 & 2004 & 2005 & 2006 \\
\hline Cow milk (L) & 3.58 & 3.54 & 3.68 & 4.14 & 4.01 & 4.04 & 4.06 \\
Buffalo milk (L) & 1.38 & 1.36 & 1.35 & 1.33 & 1.33 & 1.38 & 1.27 \\
Milk power (kg) & 3.73 & 3.64 & 3.94 & 4.10 & 3.46 & 3.63 & 4.21 \\
Condensed milk (kg) & 0.25 & 0.24 & 0.25 & 0.24 & 0.27 & 0.27 & - \\
Other milk foods (kg) & 0.08 & 0.10 & 0.11 & 0.13 & 0.15 & 0.14 & 0.15 \\
\hline
\end{tabular}

Source: Dept. of Census and Statistics, Sri Lanka ${ }^{3}$. 
million litres comprises of 120 million litres (approx. 300,000 litres per day) collected by the formal market and 100 million litres sold through the informal market. The shortfall of 480 million litres is met by imports, mostly in powder form. Thus, locally produced milk meets only $30 \%$ of the current demand for national consumption.

In a global context, Sri Lanka produces a mere 0.22 million metric tons (mmt) of milk per year, out of the total world production of around $600 \mathrm{mmt}$ (FAO, 2007). The major producers are India (80 mmt), USA (76 mmt), Germany (30 mmt), New Zealand $(12 \mathrm{mmt})$ and the Netherlands (10 mmt).

The current Government of Sri Lanka has given high priority for dairy development, with a policy target of attaining $50 \%$ self-sufficiency by 2015 . The mediumterm goal of the Ministry of Livestock Development is to double the local milk production, in respect of both

Table 3: Annual average per capita consumption of livestock products

\begin{tabular}{lccr}
\hline Product & $1980 / 81$ & $1990 / 91$ & 2006 \\
\hline Beef $(\mathrm{kg})$ & 1.63 & 1.97 & 2.82 \\
Mutton $(\mathrm{kg})$ & $\mathrm{n} / \mathrm{a}$ & 0.19 & 0.22 \\
Pork $(\mathrm{kg})$ & 0.54 & 0.15 & 0.45 \\
Chicken $(\mathrm{kg})$ & $\mathrm{n} / \mathrm{a}$ & 0.82 & 10.93 \\
Other meat $(\mathrm{kg})$ & $\mathrm{n} / \mathrm{a}$ & 0.05 & 0.30 \\
Total meat $(\mathrm{kg})$ & 2.18 & 3.18 & 14.72 \\
Cow milk $(\mathrm{L})$ & 6.14 & 4.29 & 4.54 \\
Goat milk (kg) & $\mathrm{n} / \mathrm{a}$ & $0.03-$ & \\
Condensed milk $(\mathrm{kg})$ & $\mathrm{n} / \mathrm{a}$ & 0.02 & 0.10 \\
Milk powder $(\mathrm{kg})$ & 1.63 & 2.10 & 17.41 \\
Other milk products $(\mathrm{kg})$ & - & - & 2.30 \\
Eggs (number) & 15.6 & 29.60 & 138.50 \\
\hline
\end{tabular}

Source: Dept. of Census and Statistics, Sri Lanka. Household income and expenditure surveys, 2006/2007

Table 4: Monthly average expenditure on livestock products by households in different sectors during 2006

\begin{tabular}{lcccc}
\hline Product & \multicolumn{4}{c}{ Expenditure (Rs.) } \\
& Urban & Rural & Estate & Overall \\
\hline & 1077 & 723 & 613 & 767 \\
Milk and milk foods & 10.2 & 9.3 & 9.0 & 9.5 \\
Milk and milk foods & & & & \\
(as a \% of average monthly & & & & \\
expenditure) & 584 & 262 & 206 & 305 \\
Meat & 5.5 & 3.4 & 3.0 & 3.8 \\
Meat (as a \% of average & & & & \\
monthly expenditure & & & & \\
\hline
\end{tabular}

Source: Department of Census and Statistics, Sri Lanka. Household income and expenditure survey, 2006/07. the formal and informal milk markets, thus reducing the proportion of imported milk from the current level of $70 \%$ to $35 \%$ (Table 5 ). Contribution to national production from cattle, buffaloes
and goats

As stated previously, the populations of cattle and buffalo have shown a very slow rate of increase over the past decade (Table 1). The trend in annual milk production from cattle and buffalo and the amounts collected by the formal milk collection systems over the same period, given in Table 6, show a similar slow growth.

The majority of cattle in the country are of the crossbred type, comprising mainly of crosses between the indigenous Bos indicus (Zebu) cattle and improved Zebu breeds from the Indian sub-continent, or between Zebu and Bos taurus (European/American) dairy breeds. The main improved Zebu breeds used in dairy production in Sri Lanka are Scindhi and Sahiwal, while the main European breeds used are Holstein/Friesian (Figure 1) and Jersey.

Over $90 \%$ of the buffalo (Bubalus bubalis) population is of the indigenous type, referred to as 'Lanka buffalo', kept by smallholder farmers. They are used predominantly for farm power in the cultivation of rice, but in some areas they have traditionally been milked, particularly in the South-East (Ruhuna), which is famous for buffalo curd. Lanka buffalo are located mainly in the low-country wet and dry zones and in the mid-country. The contribution of buffalo milk to the overall national milk production is around $16 \%$.

Goats are reared mainly in the dry zone, where they are kept mainly for producing meat. However, rearing of goats for milk and milk products is becoming more popular, especially in peri-urban areas due to changes in food habits of the people. The main exotic dairy breeds that have been used for crossing with indigenous goats are the Jamnapari from India and the Saanen from Europe.

Table 5: Current local production and imports of milk, and the medi um-term development targets of the Government

\begin{tabular}{lcc}
\hline Source of milk & \multicolumn{2}{c}{ Million litres/year } \\
& Current & Development target \\
\hline Local production & & \\
Formal market & 120 & 240 \\
Informal market & 100 & 200 \\
Imported (\% of total) & $480(70 \%)$ & $260(35 \%)$ \\
Total & 700 & 700 \\
\hline
\end{tabular}

Source: Ministry of Livestock Development, $2008^{8}$ 


\section{Production systems}

Cattle and buffalo management systems in different parts of the country have largely been influenced by the climate, type of crops grown and cropping pattern, availability of grazing land, genetic make-up of the animals and the main production objectives ${ }^{4}$. The major production systems have been classified as follows:

Dry Zone Traditional Village System: Mainly indigenous zebu cattle and buffalo, with some crosses with Indian breeds; kept on communal grazing lands with minimal inputs; primary income is from sales for meat and draught, with limited milk extraction from some animals over a short lactation period.

Dry Zone Irrigated Settlement System: Small herds with medium production levels; combination of tethered grazing and stall-feeding with cut grasses, tree fodders, straw and some concentrates; primary products are milk and draught, with surplus animals sold for draught and meat.

Intermediate Zone (Coconut Triangle) System: Small herds under semi-intensive system; grazing is free or tethered, on natural pasture under coconut and other perennial crops; primary products are milk and draught, with surplus animals sold for draught and meat.

Wet Zone (Mid and Up-Country) System: Intensive smallholder mixed crop-livestock production system with pure-bred or cross-bred European breeds of cattle and Indian breeds of buffalo; zero-grazing with high inputs for feed, health control and artificial breeding; primary objective is milk production with meat as a by-product.
Peri-urban System: A specialized dairy production system (not integrated with crops); high producing pure-bred European cattle and Indian buffalo kept under confinement; all fodder and concentrates are purchased from outside; primary objective is milk production with meat as a by-product (Figure 2).

Cost of production, farm gate price and price to the consumer

A survey conducted in three veterinary ranges of the Kandy District during $2007{ }^{5}$ showed that the cost of production (COP) of milk was on average Rs. 30.55 per litre, and varied widely between the different production systems studied (extensive, semi-intensive and intensive). When family labour was valued at market rates, it was the major cost component, amounting to an average of Rs. 16.60 per litre, while feed cost was Rs. 6.81 per litre and fixed costs were Rs. 6.02 per litre. Overall, labour accounted for $55 \%$ of production cost (range 13 to $86 \%$ ), while feed accounted for $22 \%$ (range 4 to $46 \%$ ). The average farm gate price of milk at the time of the survey was Rs. 23.40 per litre (range Rs. 19-31). Thus, when all fixed and variable costs were accounted for (including family labour), there was no profit from dairying under the farming systems studied.

The current price of processed liquid milk sold to consumers (as pasteurized or sterilized milk, packed in bottles or tetra-packs) ranges from Rs. 60 to Rs. 130 per litre. Thus, the margin between the farm gate price and the price to the consumer is excessively wide, and is one of the main reasons for stagnation of the dairy industry.

Table 6: Annual milk production from cattle and buffalo and the amounts collected by the formal milk collection systems (mainly processors) over the past nine years

\begin{tabular}{ccccr}
\hline Year & \multicolumn{2}{c}{$\begin{array}{c}\text { Annual milk production } \\
\text { (liters) }\end{array}$} & $\begin{array}{c}\text { Total annual } \\
\text { production } \\
\text { (liters) }\end{array}$ & $\begin{array}{r}\text { Total collected } \\
\text { by processors } \\
\text { (liters) }\end{array}$ \\
\hline & Cattle & Buffalo & & \\
1998 & $147,381,600$ & $29,707,440$ & $177,089,040$ & $100,828,000$ \\
1999 & $149,686,800$ & $30,196,800$ & $179,883,600$ & $108,863,000$ \\
2000 & $151,239,600$ & $30,210,144$ & $181,449,744$ & 92,494 \\
2001 & $152,764,800$ & $30,262,800$ & $183,027,600$ & $102,245,000$ \\
2002 & $152,840,880$ & $30,354,120$ & $183,195,000$ & $92,043,000$ \\
2003 & $156,546,000$ & $30,258,000$ & $186,804,000$ & $88,003,000$ \\
2004 & $159,696,000$ & $30,600,000$ & $190,296,000$ & $99,235,000$ \\
2005 & $161,816,400$ & $30,925,200$ & $192,741,600$ & $100,185,000$ \\
2006 & $164,862,200$ & $31,648,160$ & $196,510,680$ & $109,308,000$ \\
\hline
\end{tabular}

Source: National Livestock Statistics, 2007 


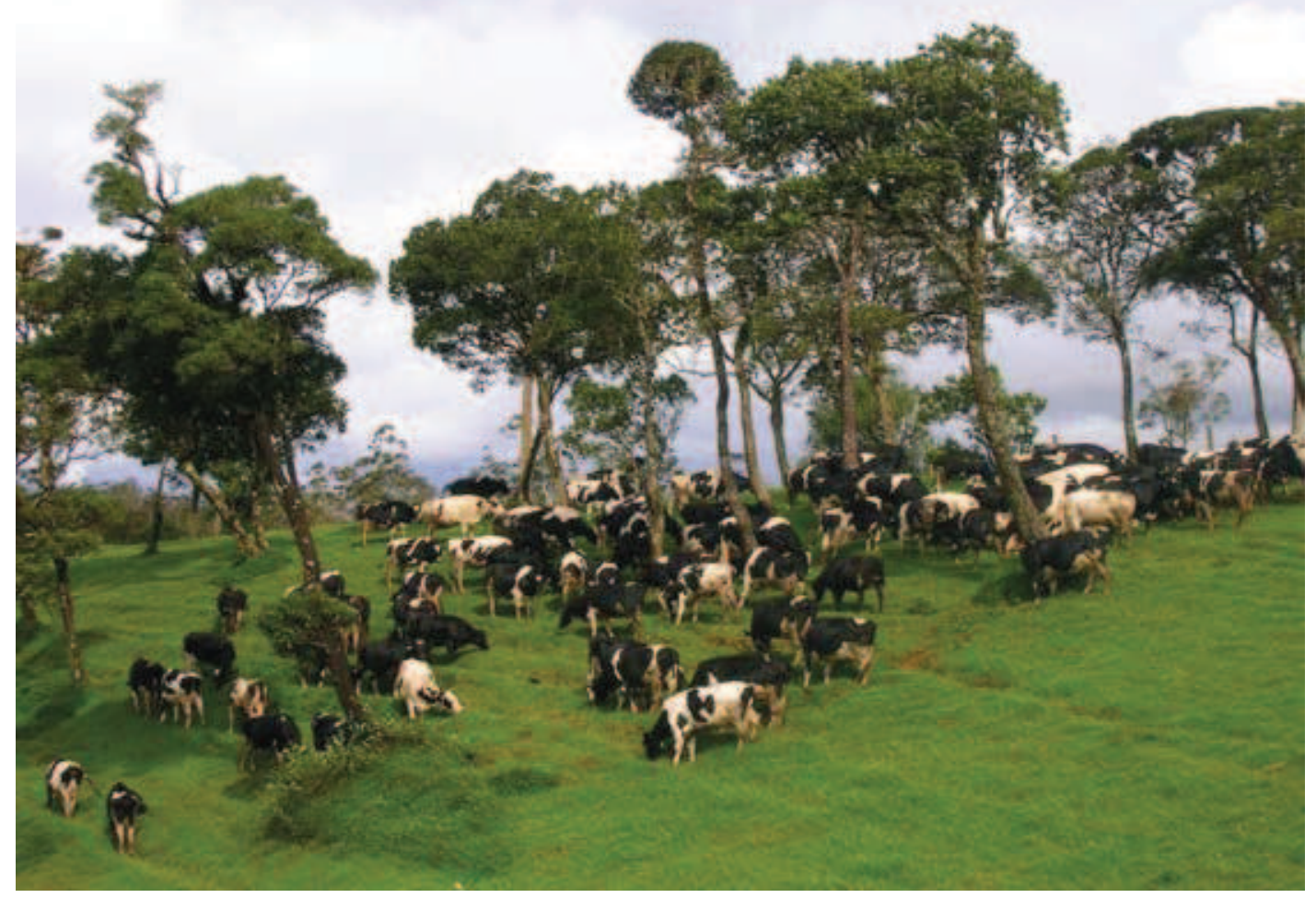

FIgure 1: Friesian cattle grazing lush pastures in the hill country

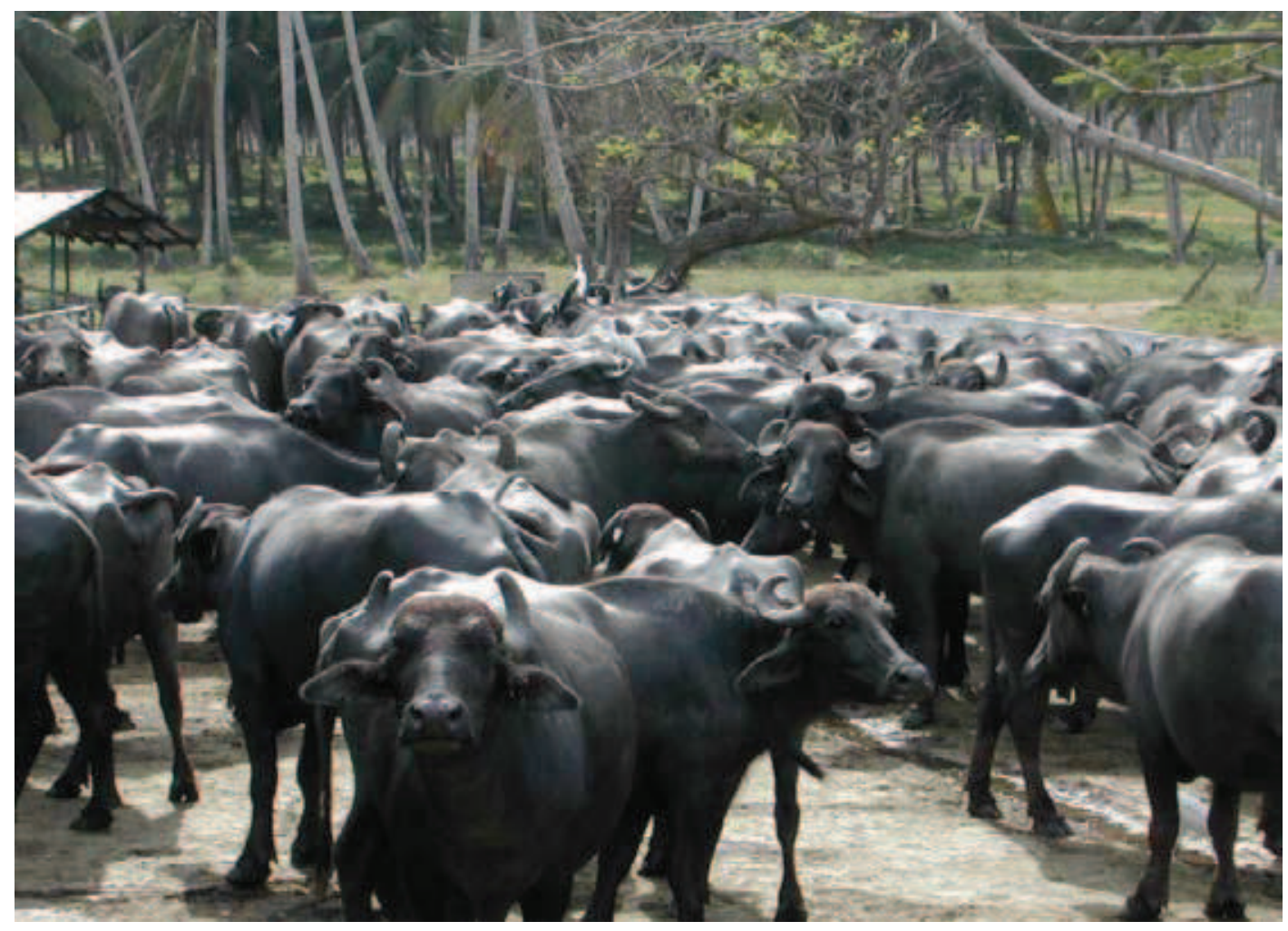

Figure 2: A herd of Murrah buffalo in the coconut triangle 


\section{Major constraints to improved milk production}

The constraints to sustainable livestock production by the resource poor farmers in developing countries have been classed into three major categories ${ }^{6}$. These are fully applicable to the current situation that prevails in Sri Lanka, and are:

- Procurement of animals: Poor farmers find it difficult to access capital and credit facilities to purchase the required breeding stock.

- Management: Farmers are unable to obtain animal health and production services, such as veterinary, breeding and advisory services in a timely and effective manner.

- Marketing: Small farmers do not have access to reliable and steady markets for their products.

Studies conducted under a SAREC/NARESA Buffalo Development Project a decade ago ${ }^{4}$ showed that the constraints faced by cattle and buffalo farmers in many regions of Sri Lanka were as follows:

- Low farm gate price of milk, which is determined by government policy and the monopolistic practices of milk collection systems. This is further influenced by:

* Lack of producer participation in collection and marketing, thereby resulting in monopolies and malpractices by the collectors and exploitation of the farmers

* Powerful advertising campaigns by importers of milk products in order to sway consumer preference away from local milk products

* Lack of milk collecting facilities in certain areas, and inadequacies even in some areas where they exist, with only morning milk being collected

- Shortage of suitable breeding stock in the country. The factors influencing this are:

* The state sector livestock farms of the National Livestock Development Board (NLDB) are mandated to supply superior breeding stock to farmers, but they are able to meet only about $20 \%$ of the demand.

* Lack of organized livestock markets for farmers to sell and buy animals

* Limitations of the artificial insemination (AI) programme, with only $10-15 \%$ of breedable cows being served by AI, and only $2-5 \%$ of calvings attributable to AI

* Lack of natural breeding (stud) services in areas where AI services are not available
- High cost of feeding dairy animals. This is influenced by:

* Seasonal fluctuations in ruminant feed resources resulting in scarcity

* High price of compounded feeds

* Lack of knowledge on methods of low-cost feed supplementation

- Lack of an appropriate long term government policy and sustained support to improve local milk production and progressively reduce imports. This is due to:

* Inadequate government support for livestock extension services in management, health, breeding and product technology

* High cost of veterinary services and drugs

* Lack of follow-up programmes by the Ministry and the DAPH to continue the livestock development programmes that were initiated and assisted by international grants and loans

* Lack of credit, tax rebates, insurance schemes and other incentives to encourage small to medium scale private enterprises in dairy production

A study commissioned by the Animal Production and Health Commission for Asia and the Pacific (APHCA) of the FAO on improved market access and smallholder dairy farmer participation for sustainable dairy development ${ }^{7}$ identified the main constraints to dairy development in Sri Lanka in five main areas as: stock availability; animal health management; land availability; farmer knowledge and skills; and extension system limitations.

Recent findings of the Ministry of Livestock Development through its studies and consultations with stakeholders in the dairy sector have shown that many of the above constraints are still present. The limitations have been categorized under four headings ${ }^{8}$ and include the following:

- Primary production level

* Non-availability of good quality dairy animals

* Inadequate coverage of AI and follow-up services

* High wastage of improved genetic material

* Inadequate feed resources

* Unfavourable ratio between farm gate price and cost of production of milk

* Limitations of research and development efforts aimed at resolving problems at the producer level 
* Non-sustainability of low input - low output and highly fragmented smallholder dairy farming system

- $\quad$ Curative and preventive animal health care delivery system

* Inadequate coverage of veterinary services catering to acute health care needs

* Inadequacy of disease surveillance and control service

* Inadequacy of man power development and training programmes

- Inefficiencies and distortions in milk marketing system

* Unsatisfactory milk collecting system

* Lack of bargaining power of smallholders

* Heavy consumer preference for milk powder

* Heavy competition from imports

* Availability of low quality milk and milk products in the market

- Other limitations

* Most of the Government and parastatal institutions are trying to do too many things with limited resources

* Weak industrial structure of the dairy industry.

Some aspects of the main technical as well as nontechnical issues and constraints are further examined below.

\section{a) Technical issues}

Shortage of quality breeding stock suited to different environments (breeding, AI and Natural Service (NS), delivery of services and follow-up): The national livestock development policy and strategy has recognized that cattle, buffalo and goats play an integral part in the rural agriculture economy, and has identified the dairy sub sector as the priority area for public sector investment in livestock development. Upgrading of the native herd is considered a fundamental necessity for dairy cattle and buffalo development. This envisages preserving the traits of technical importance which have helped native livestock to thrive in hostile environments and low quality feed, while improving their productivity. A national breeding policy for cattle, buffaloes, goats, sheep and pigs has been formulated by the National Animal Breeding Committee in 1994 to ensure uniformity of livestock breeding across the country ${ }^{9}$. The breeding objectives, policy and strategy for each livestock species in the various agro-climatic zones (hill country, mid country, low country wet, dry and coconut triangle zones and Jaffna peninsula) under intensive and extensive systems of management have been described. The general breeding strategy is to upgrade the existing livestock through cross-breeding using genetically superior breeds and thereby enhance production.

Artificial insemination has been considered the preferred method of genetic upgrading of the native herd. However, in areas where AI is not feasible, use of genetically superior stud bulls has been recommended for upgrading programmes. To achieve these objectives, the Department of Animal Production and Health (DAPH) has imported breeding bulls from time to time, and regularly imports semen from superior sires for use on the national dairy herd.

There have also been many imports of live cattle and buffalo heifers and cows to Sri Lanka by the NLDB and DAPH in the past, but these have not provided the expected impetus for dairy development. The problems of importing good quality stock are well known, and include, difficulty in locating high quality animals (due to the natural reluctance of farmers in the source countries to sell their best animals); stress and diseases caused during transport and quarantine; and failure of animals imported from temperate climates to adapt to tropical conditions. In some cases imported animals were distributed among local smallholder farmers, with disastrous results, due to the lack of adequate knowledge, skills and resources among them to manage such animals.

It is important to consolidate the contribution of the progeny of such superior imported stock in the breeding farms and improve their management conditions, before resorting to further importations. Imported stock at any future date should be located in suitable nucleus farms with facilities for better nutrition, management and healthcare. Their offspring must be managed properly and evaluated using comprehensive recording of all production data, and then subject to stringent selection for use in future breeding programmes

Feeding: seasonal shortages of green fodder and high cost of concentrates: Since ruminant livestock production in Sri Lanka is mostly in the hands of smallholder resource poor farmers who are dispersed primarily in rural areas, the feeds that are likely to be available are the natural grazing from waste land, cut and carry indigenous grass species from road sides, water ways, paddy fields and bunds, crop residues, and agricultural by-products from industry. Due to the highly seasonal 
rainfall in many parts of the country, the quality and quantity of available forage also fluctuates affecting the milk yield and lactation length of both cattle and buffalo. While in times of abundance animals are fed on good quality forage with little or no concentrate feed, in times of short supply they are fed on poor quality crop residues like cereal straws and agro-industrial by-products and high amounts of concentrate feed. The latter is found to be uneconomical but farmers adopt such strategies for purposes of sustenance. Therefore, feeding strategies need to be developed for an annual cycle and not for separate wet and dry season feeding, highlighting the need for conservation of forages and other feed resources.

The feed resources that can be used in addition to natural grasses include fibrous crop residues such as rice straw and maize stover, and agro-industrial by-products such as molasses, rice bran, waste from fruit canneries and brewer's grain. Feedstuffs that result from industrial processing of agricultural products are generally less fibrous in comparison to crop residues, being rich in protein and minerals and containing more fermentable energy. Their source of origin can be from field and plantation crops, tree crops, fruit processing industries and other miscellaneous sources ${ }^{10}$. Some non-conventional feeds like leaves and fruits from multi-purpose trees, shrubs and woody perennial plants and sugarcane tops, contain medium to high levels of protein and are considered as useful additives to low quality diets.

With the progressive decline in land available for extensive grazing and fodder production due to expansions in crop production and human settlements, only marginal and poor quality lands are left for grazing and mixed farming.
Therefore, simple and low-cost technologies in nutrition and management need to be introduced to the smallholder farmers.

However, traditional farmers who have reared cattle and buffaloes with minimal inputs do not readily accept innovations, especially when they call for extra time, money and labour. Therefore, innovative approaches that demonstrate clear economic benefits are needed to convince farmers to accept newer technologies ${ }^{11-14}$.

Studies conducted under a multidisciplinary programme to improve smallholer buffalo production ${ }^{12,15}$ have shown that simple low cost feeding systems can be developed using locally available feed resources. The strategy used was to combine natural grasses, rice straw and legume tree fodder with Urea-Molasses Multinutrient Blocks (UMMB) for use under an intensive management system.

Reproduction : An important prerequisite for the sustainability of a dairy production system is that cows must have an efficient reproductive performance ${ }^{16}$. This is essential for the production of the main commodity of interest, milk, as well as to provide replacement animals. Over and above this, and particularly in smallholder systems, the animals must provide other outputs also, which will directly or indirectly result in economic benefits to the farmer. These include, in different combinations depending on the system, meat, draught power, fuel and fertilizer. Since the continued generation of these outputs rely totally on the production of offspring, no dairy production system is sustainable without an acceptable level of reproduction.

Table 7: Reproductive indices for dairy cattle and buffaloes under optimum conditions and suggested "acceptable" performance under improved smallholder systems in tropics.

\begin{tabular}{lcccc}
\hline Reproductive Index & \multicolumn{2}{c}{ Cattle } & \multicolumn{2}{c}{ Buffalo } \\
& Optimum & Acceptable & Optimum & Acceptable \\
\hline \multirow{2}{*}{ Age at puberty (m) } & $<18$ & $<24$ & $<30$ & $<36$ \\
Age at first calving (m) & $<30$ & $<36$ & $<42$ & $<48$ \\
Calving to first service (d) & $<60$ & $<90$ & $<60$ & $<90$ \\
Calving to conception (d) & $<85$ & $<115$ & $<85$ & $<115$ \\
Calving Interval (m) & $12-13$ & $13-14$ & $13-14$ & $14-15$ \\
First service conception rate (\%) & $>60$ & $>55$ & $>55$ & $>50$ \\
Overall conception rate (\%) & $>80$ & $>75$ & $>75$ & $>70$ \\
Calving rate (\%) & $>75$ & $>70$ & $>70$ & $>65$ \\
Services per conception & $<1.6$ & $<1.8$ & $<1.8$ & $<2.0$ \\
\hline
\end{tabular}

Source: Perera, 1999 
Table 7 gives the classical optimum reproductive indices for dairy cattle, together with a suggested "acceptable" performance indices for use under the more intensive and improved smallholder conditions. A similar set of criteria is also given for buffaloes, with suitable adjustments to account for inherent differences such as later maturity of heifers and longer duration of gestation.

From the viewpoint of reproduction, the main factors which contribute to economic losses are delayed puberty, long calving intervals, short productive life (due to culling for infertility or sterility) and high calf mortality. In practical terms, the two major limitations that need to be addressed to improve cattle and buffalo fertility, and thereby the economic benefits to smallholder farmers, are poor oestrus detection and long postpartum anoestrus 17.

Improving oestrus detection needs education and motivation of farmers, proper identification and records for individual animals, and regular close observation for the occurrence of heat signs. Oestrus synchronization is an alternative procedure that could be applied in some farming systems. However, its use requires a full evaluation of the fertility status in order to select the most suitable hormonal protocol, and careful planning to ensure success.

Prevention of prolonged post-partum anoestrus is best tackled by providing farmers with information on how to manage, feed and breed their animals, in order to avoid deleterious effects of harsh climate, seasonal fluctuations in feed availability, parasitic infections and diseases. Under smallholder systems this demands a holistic approach from researchers and livestock support services, working closely with farmers to develop and transfer a package of appropriate technologies that are acceptable to them. The use of hormones and other therapeutic interventions to overcome anoestrus are unlikely to be successful unless these basic constraints are resolved.

Diseases : These can be classified broadly as infectious and non-infectious. The former are caused by bacterial, viral and parasitic agents, while the latter include mainly the metabolic or 'production' diseases.

In cattle and buffalo the most important bacterial diseases that cause economic losses through heavy mortality are Haemorrhagic Septicaemia (HS) and Black Quarter (BQ), while diseases such as mastitis and brucellosis cause losses through lowered productivity of milk and offspring, respectively. The most important viral disease of both species is foot-and-mouth disease (FMD), which is highly infectious but rarely fatal, causing economic loss through lowered productivity.

Important parasitic diseases include those caused by gastrointestinal parasites such as round worms (nematodes), flukes (trematodes) and tape worms (cestodes), which cause mainly insidious losses due to poor growth and development in young animals. Blood parasites such as Babesia and Theileria are of importance in pure-bred European cattle and their crosses, sometimes causing high mortality.

Goats are generally not prone to major bacterial and viral diseases of epizootic nature. However, parasitic diseases do cause losses, mainly in young kids. A specific problem is Cerebro-Spinal Nematodiasis, which is caused when a parasite that lives harmlessly in the peritoneum of cattle (Artionema digitata) infects goats and migrates to the central nervous system.

Young cattle, buffalo and goats are susceptible to intestinal and lung disturbances, the former causing diarrhoea and the latter pneumonia, both of which can result in high mortality. The common bacterial causes of diarrhoea are Escherichia coli and Salmonella spp., while the main parasitic cause is Coccidia spp. Aetiological agents for pneumonia can be viruses, bacteria or both. Viruses usually play the role of primary pathogens, while bacterial infection sets in as secondary invaders under the lowered body resistance in affected animals. Environmental factors such as adverse weather, ambient temperature, poor ventilation, overcrowding and poor management can precipitate respiratory disease $\mathrm{e}^{18,19}$. Improvement of housing, hygiene and management practices can reduce the incidence of diarrhoea and pneumonia to a great extent.

\section{b) Other issues}

The 'National Livestock Development Policy and Strategies' published by the Ministry of Livestock Development in 2006 states that the dairy sector will be given priority for public sector investment in livestock development. Several strategies for improving the diary industry have been outlined in general terms, and include the following:

- Promoting and expanding the liquid milk market

- Upgrading the native herd

- Facilitating the transformation of the present subsistence level dairy producers/farmers into commercially viable and sustainable enterprises

- Further developing the medium and large scale private sector dairy producers 
- Allowing market forces to govern the pricing mechanism of domestic milk

- Encouraging the private sector dairy processors to contribute to dairy development

However, implementing these strategies requires a clear long-term policy backed by actions and investments that will effectively address the limitations, inequalities and deficiencies that exist in the dairy industry as a whole. As discussed above, one of the major dis-incentives to dairy development is the low farm-gate price of milk and problems in marketing. Lack of credit and other support services for the diary industry are a further deterrent for the smallholder farmers to evolve in to more commercially oriented medium-scale entrepreneurs.

In Sri Lanka there is no beef cattle industry, and beef is a by-product of the dairy industry. However, the current policies and practices are not conducive for farmers to derive an income from raising any surplus stock for meat. The ban on slaughter of females and the problems in the meat marketing system make it impossible for farmers to dispose of non-productive females and excess males, thus making such animals an economic burden on the farmer.

A recent consultancy undertaken by ANZDEC 20 for the Ministry of Livestock Development has analysed the main impediments to developing the dairy industry and increasing domestic milk production, and has recommended the following strategy:

- Government provides a sustainable solution to the pricing of imported milk powder;

- Government and industry together encourage investment by private investors into large-scale commercial dairy clusters;

- Government works with smallholders to link them to large-scale commercial dairy farms for the purpose of increasing smallholder milk production and income from dairying;

- Government needs to complete a major overhaul of all the government agencies involved in the dairy sector - the Ministry of Livestock, Department of Livestock, Milco, and NLDB;

- Industry works to develop industry-wide quality standards for milk that is commercially collected, and establishes an industry promotion programme for the consumption of liquid milk.

This proposed strategy outlined by ANZDEC adopts a fundamentally different approach to those taken previously, by harnessing commercial investment to create growth in the industry, and involves adding commercial production capacity on top of the existing rural householder milk production system. It requires major policy changes, strong commitment and sustained implementation by the Government in partnership with private investors, and could be an effective way for overcoming the stagnation that the dairy industry has suffered in the past.

\section{Research and development needs for improving the dairy industry}

From a global perspective, $\mathrm{FAO}^{21}$ considers the following aspects to be of importance in promoting and improving livestock production from a "pro-poor" approach:

- Establishing the basis for livestock production: Providing adequate and secure access to basic inputs required, such as land, water and feed, and risk coping mechanisms.

- Kick-starting domestic markets for livestock and livestock-derived products: Providing secure access to livestock support services, credit and output markets.

- Sustaining and expanding livestock production: Securing the quality and food safety of livestock products, promoting research on breeding and feeding to produce high quality animals and products, and ensuring environmental sustainability of livestock production.

While some of these are clearly outside the scope of research and deal with policy issues, it is important to note that without such enabling policies and support services the results of research will have limited applications for improving livestock production.

The research and development priorities for the livestock sector in Sri Lanka have been the subject of several workshops and consultations with researchers and other stakeholders. The Sri Lanka Council for Agricultural Research Policy (CARP) has compiled a document based on such consultations ${ }^{22}$ under the subject areas of breeding, reproduction, nutrition, health and product technologies. The summary given below of priority research areas under different subjects or "themes" is based on a CARP document as well as other publications and the experience of the authors.

Increasing the availability of quality animals suitable for different environments and production systems

The objectives under this theme should be to produce animals with optimum production performance, which are abletosurviveundertheexistingenvironmentalconditions, utilizing locally available resources; and to develop methods and procedures for optimizing their reproduction 
and productivity cost-effectively. The research required would include the development of selection criteria for different breeds of ruminants suitable for different production systems, determining the cost-effectiveness of different genotypes under specific farming systems, establishment of sustainable breeding programmes for commercial as well as conservation purposes, and the development or adaptation and application of modern technologies for improving productivity.

\section{Development of low-cost feeding strategies using locally available feed resources}

The research needed under this theme includes methods for improving the utilization of locally available feed resources to obtain optimum production of milk and meat from ruminants. This would involve the development, utilization and conservation of forage resources, both natural and cultivated, as well as development of novel feedstuffs from agricultural by-products.

\section{Improving the management skills of farmers}

This area needs studies to develop appropriate educational and extension materials and to deliver them to farmers through the most effective media using modern communication methods. The ubiquitous cellular phone which is now common among village farmers could be a novel approach to farmer education in the future.

\section{Provision of reliable breeding and follow-up services}

The delivery of AI and related support services has been a major bottleneck for improving dairy production. Improved methods and modalities for providing the required services, their monitoring and continuous improvement should be the focus of research in this area.

Controlling diseases, including sub-clinical and production diseases

The research under this theme should include studies that will produce the information needed for making and implementing policies and programmes to control and eradicate existing infectious diseases, and to prevent losses due to parasitic, metabolic and sub-clinical diseases. The studies should focus on improving the efficacy of locally produced vaccines (e.g. for Haemorrhagic Septicaemia and Black Quarter), quality control of imported vaccines, improved methods for the diagnosis and control of common parasitic and production diseases, as well as surveillance to prevent the introduction of exotic diseases (e.g. Bovine Spongioform Encephalopathy, Contagious Bovine Pleuro-pneumonia and Bovine Viral Diarrhoea).

\section{Improving the quality and safety of livestock products}

Studies are needed in this area to provide the information needed for making and implementing policies on setting standards and improving the quality and safety of livestock products as well as of animal feeds and pharmaceuticals that influence animal products. This should include studies on ingredients used in the value addition of dairy and meat products, and methods for improving the quality of animal products through advanced technologies. Surveys are also needed to identify unhygienic practices in relation to milking, slaughter and subsequent processing of milk and meat products, and on the usage, quality and safety of animal feeds, pharmaceuticals, biologicals and chemicals used in agriculture and veterinary practices.

Other areas requiring study in this theme include methods for narrowing the gap between the farm-gate price and the consumer sale price of milk, the salvage and rearing of male stock for meat, and methods for optimally using livestock by-products and excreta.

\section{CONCLUSION}

Smallholder dairy farmers represent some of the "poorest of the poor' among the rural sector. Improving production of their livestock would therefore be one of the best ways of raising their livelihoods and transforming them from one of poverty to relative prosperity.

The prevailing constraints, limitations and shortcomings as identified above have to be addressed and rectified urgently with adequate investment and participation of both the government and the private sector. If livestock production is to be a profitable enterprise and the government is to achieve its proposed targets, there is a need for smallholder farmers to be linked to largescale commercial dairy farms. Both the government and industry together should also encourage investment by private investors into large-scale commercial dairying.

\section{References}

1. Ministry of Livestock Development and Estate Infrastructure (1996). Annual Report. Ministry of Livestock Development and Estate Infrastructure, Colombo.

2. Central Bank of Sri Lanka (2006). Annual Report. Central Bank of Sri Lanka, Colombo.

3. Department of Census and Statistics (2006). Statistical Abstracts. Department of Census and Statistics, Colombo.

4. Abeygunawardena H. \& Abeygunawardena I.S. (1998). Water buffalo farming in Sri Lanka: Production systems, 
uses, potentials and constraints. In: Water Buffalo - Improved Utilization Through New Technologies, (Eds. D.H.A. Subasinghe, N.U. Horadagoda, H. Abeygunawardena \& J.A.de S.Siriwardena), pp.11-22 National Science Foundation, Colombo.

5. Kothalawala K.A.C.H.A. (2008). Survey on cost of production of milk. Livestock Statistical Bulletin No. 1, Issue 1. Department of Animal Production and Health, Peradeniya.

6. Hefferman C., Nielson L., Sidhamed A. \& Miha T. (2005). Livestock development and poverty. In: Livestock and Wealth Creation - Improving the Husbandry of Animals Kept by Poor People in Developing Countries (Eds. E. Owen, A. Kitalyi, N. Jayasuriya, \& T. Smith). pp. 71-87. Livestock Production Programme, Natural Resources International Limited, United Kingdom.

7. Ranaweera N.F.C. (2007). Improved Market Access and Smallholder dairy farmer participation for sustainable dairy development: Lessons learned - Sri Lanka. Food and Agriculture Organization, Regional Office for Asia and the Pacific, Bangkok, Thailand.

8. Ministry of Livestock Development (2008). Discussion paper on public-private joint program for development of the dairy industry in Sri Lanka. Ministry of Livestock Development, Colombo.

9. Ministry of Livestock Development and Estate Infrastructure (1994). The National Breeding Policy for Livestock in Sri Lanka. Ministry of Livestock Development and Estate Infrastructure, Colombo.

10. Smith T., Jayasuriya M.C.N., Mlambo V., Lekule F., Thomas D., Owen E., Pearson A., \& Titterton M. (2005). Feeds and feeding to improve productivity and survival. In: Livestock and Wealth Creation. Improving the Husbandry of Animals Kept by Resource-poor People in Developing countries. (Eds. E. Owen, A. Kitalyi, N. Jayasuriya \& T. Smith), pp. 191-213. Livestock Production Programme, Natural Resources International Limited, United Kingdom.

11. Jayasuriya M.C.N. (2000). Technologies for improving buffalo nutrition: trends and prospects. In: Changing role of the buffalo in the new millennium in Asia. (Eds. J.A.de S. Siriwardena, D.H.A. Subasinghe, N.U. Horadagoda \& H. Abeygunawardena), pp. 157-166. National Science Foundation, 47/5, Maitland Place, Colombo 7.

12. Abeygunawardena H., Subasinghe D.H.A., Ranawana S.S.E., Jayatilaka M.W.A.P. \& Perera B.M.A.O. (1996). Transfer of technology in smallholder intensive buffalo farming: results from a pilot study in Mahaweli System "H". In: The Role of the Buffalo in Rural Development in Asia. (Eds. B.M.A.O. Perera, J.A. de S. Siriwardena,
N.U. Horadagoda \& M.N.M. Ibrahim) pp. 67-94. Natural Resoures Energy and Science Authority, 47/5, Maitland Place, Colombo 7.

13. Abeygunawardena H., Subasinghe D.H.A., Perera A.N.F \& Perera B.M.A.O. (1997). Farming systems research approach to technology generation and transfer in smallholder buffalo production systems in Sri Lanka. Proceedings of the $5^{\text {th }}$ World Buffalo Congress 13-16 October, 1997, Caserta, Italy.

14. Perera B.M.A.O., Abeygunawardena H., Vale W.G. \& Chantalakhana C. (2005). Buffalo. In: Livestock and Wealth Creation - Improving the Husbandry of Animals Kept by Poor People in Developing Countries (Eds. E. Owen, A. Kitalyi, N. Jayasuriya \& T. Smith), pp. 451-471 Livestock Production Programme, Natural Resources International Limited, United Kingdom.

15. Abeygunawardena H. \& Siriwardena J.A.De S. (1999). Cattle and Buffalo Farming. In: Handbook for Veterinarians. National Science Foundation, 47/5, Maitland Place, Colombo 7.

16. Perera B.M.A.O. (1999a). Management of reproduction. In: Small-holder Dairying in the Tropics (Eds. L. Falvey \& C. Chantalakhana). pp. 241-264. International Livestock Research Institute, Nairobi, Kenya.

17. Perera B.M.A.O. (1999b). Reproduction in water buffalo: comparative aspects and implications for management. Journal of Reproduction and Fertility, Supplement 54: 157-168.

18. Horadagoda N.U. (1999). Respiratory diseases. In: Water Buffalo in Asia IV: Diseases of the Buffalo (Eds. M.C.L. de Alwis, D.H.A. Subasinghe \& N.U. Horadagoda), pp.125127. National Science Foundation 47/5, Maitland Place, Colombo 7.

19. Subasinghe D.H.A. (1999). Healthcare and disease prevention. In: Water Buffalo in Asia IV: Diseases of the Buffalo. (Eds. M.C.L. de Alwis, D.H.A.Subasinghe \& N.U.Horadagoda), pp.129-152. National Science Foundation 47/5, Maitland Place, Colombo 7.

20. ANZDEC (2007). Sri Lanka dairy sector strategy and action plan; Prepared for the Ministry of Livestock Development, Colombo. ANZDEC Limited, Newmarket, Auckland, New Zealand.

21. Livestock policies for poverty alleviation - Practical evidence from Africa, Asia and Latin America. http:// www.fao.org/ag/againfo/projects/en/pplpi/resources.html

22. Sri Lanka Council for Agricultural Research Policy (2007). Research Priorities in Livestock, Aquaculture and Inland Fisheries: 2007-2011. National Committee on Livestock, Aquaculture and Fisheries, Sri Lanka Council for Agricultural Research Policy, Colombo 7. 